\title{
Effects of informal controls and psychological empowerment on job satisfaction*
}

\author{
Ana Paula Capuano da Cruz ${ }^{1}$ \\ (D) https://orcid.org/0000-0002-6064-1614 \\ Email: anapaulacapuanocruz@gmail.com \\ Anderson Betti Frare ${ }^{2}$ \\ (D) https://orcid.org/0000-0002-4602-7394 \\ Email: anderson_betti_frare@hotmail.com \\ Monique Couto Accadrolli ${ }^{3}$
(D) https://orcid.org/0000-0002-0381-1672
Email: moniqueaccadrolli81@gmail.com \\ Vagner Horz ${ }^{4}$ \\ (D) https://orcid.org/0000-0002-7420-9750 \\ Email: vagnerhorz@gmail.com
}

\begin{abstract}
${ }^{1}$ Universidade Federal do Rio Grande, Programa de Pós-Graduação em Contabilidade, Rio Grande, RS, Brazil
${ }^{2}$ Universidade Federal de Santa Catarina, Programa de Pós-Graduação em Contabilidade, Florianópolis, SC, Brazil

${ }^{3}$ Universidade Federal do Rio Grande, Instituto de Ciências Econômicas, Administrativas e Contábeis, Rio Grande, RS, Brazil

${ }^{4}$ Universidade Regional de Blumenau, Programa de Pós-Graduação em Ciências Contábeis, Blumenau, SC, Brazil
\end{abstract}

Received on 05.17.2021 - Desk acceptance on 06.17.2021 - $2^{\text {nd }}$ version approved on 09.15.2021

Editor-in-Chief: Fábio Frezatti

Associate Editor: Cláudio de Araújo Wanderley

\begin{abstract}
The aim of this article was to investigate the effects of informal controls on psychological empowerment and job satisfaction. Despite previous studies having analyzed the role of certain management control systems in individual results, such as psychological empowerment and job satisfaction, the evidence on informal controls within this context is inconclusive. Credit union systems play a considerable role in economic growth, regional development, and employability. We therefore explore the perception of directors and managers of business units of one of the biggest cooperative systems regarding the informal controls used. Considering that job satisfaction has a series of implications for organizations (for example in employee loyalty and job performance), it is important to understand its determinants. The literature points to the growing concern among contemporary organizations about informal controls. Various studies focus on understanding the role of these controls and their respective effects on organizational and individual behaviors. From the individual perspective, there is a need to analyze the indirect effects of management controls on individual aspects by means of psychological variables. Thus, this study provides new evidence on informal controls in organizations by exploring the intervening role of psychological empowerment and the (beneficial) effects on job satisfaction. In addition, the study provides a methodological contribution to the national research on management control by adding an analysis based on mixed methods. A survey was applied to directors and managers of business units of one of the biggest credit union systems in Brazil. The data were analyzed using a mixed methods approach: partial least squares structural equation modeling and fuzzy-set qualitative comparative analysis. Informal controls are directly and indirectly associated (via empowerment) with job satisfaction. Moreover, the findings indicate more than one solution for high job satisfaction.
\end{abstract}

Keywords: management controls, informal controls, psychological empowerment, job satisfaction.

Correspondence address

Ana Paula Capuano da Cruz

Universidade Federal do Rio Grande, Programa de Pós-Graduação em Contabilidade

Av. Itália, Km 8, s/n - CEP 96201-900

Rio Grande - RS - Brazil

\footnotetext{
*The authors are grateful to the Coordination for the Improvement of Higher Education Personnel (Capes) and to the National Council for Scientific and Technological Development (CNPq) for their financial support in conducting this study.
} 


\section{INTRODUCTION}

Management control systems (MCS) are essential for organizations and maintaining control has become a critical element in most companies (Goebel \& Weißenberger, 2017a, 2017b). The importance of MCS lies in the fact that they represent a management tool designed to enable the achievement of organizational objectives, and this naturally requires the collaboration of a significant contingent of people (Merchant \& Van der Stede, 2007). Thus, many businesses have endeavored to create work environments that meet the desires of their employees (Altenburger, 2021). In this sense, the author highlights that Google is a classic example of a company that invests in order to increase job satisfaction and that unsatisfied workers can lead to highly unfavorable consequences for companies, such as lost productivity, which compromises the achievement of planned objectives and the overall strategy.

Within this context, understanding what lies behind job satisfaction could help organizations to maintain a positive environment that contributes to the proposed objectives actually being achieved by the team. Studies indicate that job satisfaction can be associated with perceived environmental uncertainty (Ferris, 1977), professionalism and commitment (Norris \& Niebuhr, 1984), a participatory budget (Chenhall \& Brownell, 1988), psychological empowerment (Bordin et al., 2006), commitment and turnover (Rajabi et al., 2021), among other factors.

Standing out among motivational factors related to work is psychological empowerment, a multifaceted construct (Thomas \& Velthouse, 1990) that indicates the intrinsic motivation and attitudes of a subject in relation to their work environment as a whole (Spreitzer, 1995); that is, it is a construct related to increased intrinsic motivation manifested in a set of cognitions, such as meaning, competence, self-determination, and impact. According to Hall (2008), higher levels of these four elements result in more attention and intensity in the realization of tasks, as well as potential strategic improvements in the ways those tasks are carried out.

As management controls are used to guide behaviors that are consistent with organizational strategies (Merchant \& Van Der Stede, 2007), when managers seek information about opportunities and threats in their environments in order to develop such strategies, the chances of success in that task are increased if they are supported by teams that work proactively in relation to the motivations suggested by MCS (Matsuo et al., 2021). For that reason, this study explores the role of informal controls in psychological empowerment and job satisfaction. Although the literature recognizes that management control is enabled through formal and informal controls (Goebel \& Weißenberger, 2017a, 2017b), this study exclusively explores controls of an informal nature.

The focus of the investigation is on informal controls, given that in contemporary organizations the presence of informal controls focused on culture and personnel is strongly recommended (Dimes \& Villiers, 2020; Goebel \& Weißenberger, 2017b). Informal controls are more flexible and less restrictive than formal ones, as they are not based on explicit and easily verifiable metrics (Norris \& O'D wyer, 2004). In general, informal controls are neither codified nor consciously designed, and they are less bureaucratic and explicit in organizations (Cardinal et al., 2004; Langfield-Smith, 1997). Although informal control mechanisms may contain formal aspects (e.g. explicit codifications of core values and procedural manuals), they are usually "considered more informal than formal due to their indirect influence on employees' behavior" (Goebel \& Weißenberger, 2017b, p. 509). Due to the fact that informal controls are related with intrinsic rewards (Akroyd \& Kober, 2020; Chenhall, 2003), such as autonomy and the opportunity for growth, they can potentially promote employees' psychological empowerment and satisfaction.

Given the increasing call to explore the role of informal controls (Pant, 2001; Tucker, 2019), various studies have emerged to provide new evidence, such as in contemporary organizations (Goebel \& Weißenberger, 2017b), small businesses (Wohlgemuth et al., 2019), and family businesses (Monteiro \& Lunkes, 2021). Along this line, this investigation explores the opportunity to study a cooperative financial system, which potentially enables an environment that is conducive to the use of informal control mechanisms (Williams, 1986), given that these organizations are anchored in social and collective values (Jovanović et al., 2017) and this is consequently reflected in their practices and management control mechanisms (Silva et al., 2021).

In addition, Beuren, Santos, Bernd, and Pazetto (2020) suggest that new studies on cooperative organizations investigate the effect of informal controls on aspects concerning the social spectrum, which contemplates, for example, members' well-being. Given the contextualization and evidence laid out, which reveal the research gaps, our 
aim is to investigate the effects of informal controls on the psychological empowerment and job satisfaction of organizational actors in a cooperativist financial system.

The findings of this investigation indicate that informal controls are positively associated with psychological empowerment and job satisfaction. Regarding psychological empowerment, it was proven that there is a positive association with job satisfaction and that the construct plays a mediating role in the relationship between informal controls and job satisfaction. These results suggest that organizations can benefit from using personnel and cultural control mechanisms (the informal controls investigated) to promote employees' psychological empowerment and satisfaction. As a result, we hope this finding will contribute to increasing stimuli for behaviors that are more geared toward organizational strategy.

The study has various implications and provides several contributions to the literature and to managerial practice. On one hand, it offers evidence and answers the call of Hall (2016) and Luft and Shields (2003) by analyzing the mediating effect of a psychological variable (psychological empowerment) between management controls (informal control mechanisms) and individual behaviors/results (job satisfaction). It also specifically contributes to the literature on MCS (Beuren, Santos \& Bernd, 2020; Hall, 2008; Matsuo et al., 2021; Souza \& Beuren, 2018) by exploring new relationships in which psychological empowerment acts as a facilitator. Moreover, it provides new evidence on informal controls in organizations (Goebel \& Weißenberger, 2017b; Monteiro \& Lunkes, 2021; Wohlgemuth et al., 2019), especially in cooperative environments. On the other hand, contributions are made to managerial practice by indicating effects of the MCS used on workers' behaviors and results.

In addition to this introduction, the research is structured as follows: section 2 presents the literature review and development of the hypotheses regarding the effect of informal controls on psychological empowerment $\left(\mathrm{H}_{1}\right)$ and on job satisfaction $\left(\mathrm{H}_{3}\right)$ and the effect of psychological empowerment on job satisfaction $\left(\mathrm{H}_{2}\right)$ and in mediating the relationship between informal controls and satisfaction $\left(\mathrm{H}_{4}\right)$. Section 3 describes the methodology employed to develop the survey, which featured the collaboration of 115 directors and managers of one of the biggest cooperative financial systems in Brazil and whose data were analyzed using a mixed methods approach: partial least squares structural equation modeling (PLSSEM) and fuzzy-set qualitative comparative analysis (fsQCA). Section 4 presents the analysis and discussion of the results and, finally, section 5 presents the conclusions of the investigation, its implications, its limitations, and suggestions for future research.

\section{LITERATURE REVIEW AND DEVELOPMENT OF THE HYPOTHESES}

\subsection{Informal Controls and Psychological Empowerment}

MCS are used in organizations to ensure employee behavior is consistent with organizational strategies and objectives (Merchant \& Van Der Stede, 2007). Management control can be conducted via informal (cultural and personnel controls) and formal mechanisms (result and action controls) (Merchant, 1985; Merchant \& Van Der Stede, 2007).

Formal controls are essentially based on explicit and quantifiable standards meant to ensure the achievement of intended results and an understanding of the practices adopted (Langfield-Smith, 1997). Formal controls cover employee monitoring and performance evaluations, including action controls to ensure that employees perform their tasks according to the organization's norms and procedures (Goebel \& Weißenberger, 2017b). Informal controls are more implicit and less quantifiable, acting as guidelines for employees' human behavior (Goebel \&
Weißenberger, 2017b). Along this line, informal controls relate to the means used by management to promote more informal and flexible communication with employees (Tucker, 2019) and imply personnel and cultural controls (Goebel \& Weißenberger, 2017a, 2017b). Personnel controls are employed to promote individuals' motivation and need to be consistent with the organization's values (Abernethy \& Brownell, 1997). Cultural controls seek to establish norms and values expected by the company, shaping the internal environment and individuals' mentality (Akroyd \& Kober, 2020; Goebel \& Weißenberger, 2017b).

It is perceived that informal controls relate to the routines, procedures, and practices that collectively generate and transmit information via interpersonal relationships that prevail in an organization to influence, maintain, or alter standards in organizational activities, according to the values the company intends to cultivate (Akroyd \& Kober, 2020; Tucker, 2019). Informal control mechanisms are needed to achieve organizational performance, via employees' engagement and control 
of their activities (Goebel \& Weißenberger, 2017b; Pfister \& Lukka, 2019). As informal controls are more organic than formal controls, they are potentially linked to incentivizing positive behaviors among employees (Chenhall, 2003).

With this context, the aspects concerning human behavior are the main explanation for the variation in the performance of organizations, in which psychological empowerment can lead to positive results by enabling employees to have greater engagement, control, and autonomy in their activities, which are manifested via the individual's joint perception of feelings of meaning, impact, competence, and self-determination (Spreitzer,1995). From an individual viewpoint, psychological empowerment is expressed by: (i) meaning, which covers the perception of the importance of the work carried out; (ii) competence, which consists of job-related self-confidence and abilities; (iii) self-determination, regarding autonomy and independence to carry out the work; and (iv) impact, regarding influence and control in the work department (Spreitzer, 1995). The process of individuals' psychological empowerment over their own effectiveness at work contributes to enhancing the procedures carried out, thus improving the achievement of organizational objectives (Spreitzer et al., 1997).

With respect to evidence concerning MCS and psychological empowerment, the study of Baird et al. (2018) stands out, which concluded that the enabling use of MCS is associated with the psychological empowerment of directors and organizational performance. In turn, Beuren, Santos, and Bernd (2020) highlighted that an enabling perception of MCS leads to psychological empowerment, which induces managers' organizational resilience. Finally, Matsuo et al. (2021) found that the interactive use of MCS positively affects employees' psychological empowerment, proactive behavior, and performance.

For the context of informal controls and psychological empowerment, the evidence is more limited, which reinforces the importance of this study. However, the literature reveals that informal controls are one of the main means for ensuring employees' organizational commitment (Goebel \& Weißenberger, 2017a), participation and social interaction (Wohlgemuth et al., 2019), and organizational identification (Monteiro \& Lunkes, 2021). In general, the literature suggests that informal control mechanisms promote higher levels of autonomy and psychological empowerment among employees (Merchant et al., 2003). Based on the above and on the cooperativist context of the sample, which includes institutions anchored in social and collective values (Jovanović et al., 2017) and that seek to demonstrate social responsibility (Beuren, Santos, Bernd \& Pazetto, 2020), the first hypothesis of this research is developed:

$\mathrm{H}_{1}$ : informal controls are positively associated with psychological empowerment.

\subsection{Psychological Empowerment and Job Satisfaction}

Psychological empowerment can be understood as a subject's own motivation or psychological attitude in relation to their work environment (Spreitzer, 1995; Spreitzer et al., 1997). This definition is one of the most recurrent in the literature on psychological empowerment (Meyerson \& Kline, 2008) and is essentially based on Thomas and Velthouse (1990). Among the concepts of empowerment is the distribution of authority and responsibility for decision making among employees from lower and higher levels of the institution, granting them a certain amount of arbitrariness to make decisions on their own and be responsible for the excellence of their actions to improve the functioning of the institution (Barton \& Barton, 2011; Siegall \& Gardner, 2000). There are indications that psychological empowerment may be associated with job satisfaction for employees.

Job satisfaction can be defined as the emotional state resulting from the job characteristics and work environment of employees, in which satisfaction is considered a decisive source of organizational efficiency and effectiveness (Sandalika \& Jayasekara, 2017). Job satisfaction is a result of the analysis employees make of the combination of general or specific aspects of the work environment, which directly impacts the way tasks are carried out (Saridakis et al., 2018).

In the literature, studies indicate that job satisfaction is positively associated with individual results, as well as job stability and performance, emotional rewards, and effective commitment (Koo et al., 2019; Mahmood et al. 2019). According to Bordin et al. (2006), psychological empowerment and its respective dimensions are capable of positively impacting job satisfaction, and $\mathrm{He}$ et al. (2010) obtained empirical evidence in this sense. In light of the above, the logic of the literature is expected to be supported for the employees of a cooperativist system. Therefore, the second hypothesis investigated is the following:

$\mathrm{H}_{2}$ : psychological empowerment is positively associated with job satisfaction. 


\subsection{Informal Controls and Job Satisfaction}

Informal controls normally represent informal communications of a more flexible nature in organizations (Chenhall, 2003); they contain a lower amount of objectivity, they tend not to be codified, and their conception does not necessarily occur in a conscious way, but rather they include less explicit policies and practices, which emerge from day-to-day actions (Akroyd \& Kober, 2020; Langfield-Smith, 1997). Altenburger (2021) reinforces that satisfied employees display promising behaviors for organizations, in the sense of contributing so that actions occur according to what is intended. As they are related with more intrinsic rewards, such as autonomy and the opportunity for growth, for example, informal controls may have a significant influence on behaviors, performing a relevant role in the task of promoting employees' intrinsic motivation (Goebel \& Weißenberger, 2017b).

An extensive body of research has focused on exploring antecedents of job satisfaction; however, influences of social elements have been ignored by the researchers (Macintosh \& Krush, 2014). Penha et al. (2016) argue that the social and organizational context is one of the main elements responsible for variations in levels of employee job satisfaction; that is, organizational practices influence job satisfaction. Evidence suggests that organizational socialization mechanisms, based on core values (Song et al., 2015), and the respective dissemination of those principles among the members of the work environment (Carbonell \& Rodriguez-Escudero, 2013) are relevant means for promoting employee job satisfaction. The evidence generally suggests that informal controls, anchored in the organization's implicit norms and dissemination of values (Goebel \& Weißenberger, 2017b), are beneficial for employees. Thus, personnel and cultural controls are expected to be positively associated with that emotional state, and the third research hypothesis is formulated:

$\mathrm{H}_{3}$ : informal controls are positively associated with job satisfaction.

\subsection{Informal Controls, Psychological Empowerment, and Job Satisfaction}

It is necessary to consider indirect effects of management control on outputs at an individual level, considering the mediation of psychological variables, and there is a demand for studies that contemplate that perspective (Hall, 2016; Luft \& Shields, 2003). In this sense, related studies employ psychological empowerment as a mediating variable. The mediating role of this construct is highlighted in relationships such as between the psychological environment and job satisfaction (Carless, 2004), between the comprehensive performance measurement system (PMS) and management performance (Hall, 2008), between an enabling PMS and both task performance and job satisfaction (Souza \& Beuren, 2018), between an enabling perception of the MCS and organizational resilience (Beuren, Santos \& Bernd et al., 2020), and between the interactive use of the MCS and both innovative behavior and performance (Matsuo et al., 2021).

There is also evidence that informal controls indirectly benefit individual behaviors. For example, Monteiro and Lunkes (2021) highlighted the indirect effects of informal controls on affective commitment, by means of organizational identification. The indications lead to the belief that psychological empowerment can assume an intervening role in the relationship between the informal controls used by the cooperativist system and the job satisfaction of the directors and managers of the units. Within the context of cooperativism, informal control mechanisms emerge with a considerable degree of autonomy, in which the necessary information is transmitted between superiors and subordinates (Silva et al., 2021), facilitating the dissemination of the organization's core values. This practice tends to be directly and indirectly reflected in employees' behaviors and results.

In essence, it is suggested that by means of controls over hiring, training, development, and opportunities (personnel controls) and codes of conduct, the mission, vision, and core values (cultural controls) (Goebel \& Weißenberger, 2017b; Kleine \& Weißenberger, 2014) proposed by the management of the cooperativist system, the employees' meaning, competence, self-determination, and impact (psychological empowerment) are supported (Spreitzer, 1995; Spreitzer et al., 1997) and, consequently, their feelings of accomplishment, of emotion, and that the work is worthwhile (job satisfaction) (Macintosh \& Krush, 2014; Rutherford et al., 2009). Psychological empowerment is generally expected to promote an alignment between informal controls and job satisfaction. The following is thus proposed:

$\mathrm{H}_{4}$ : psychological empowerment mediates the relationship between informal controls and job satisfaction.

Figure 1 illustrates the conceptual model of the research. In addition, three control variables are included in the model: formal controls, age, and gender. 


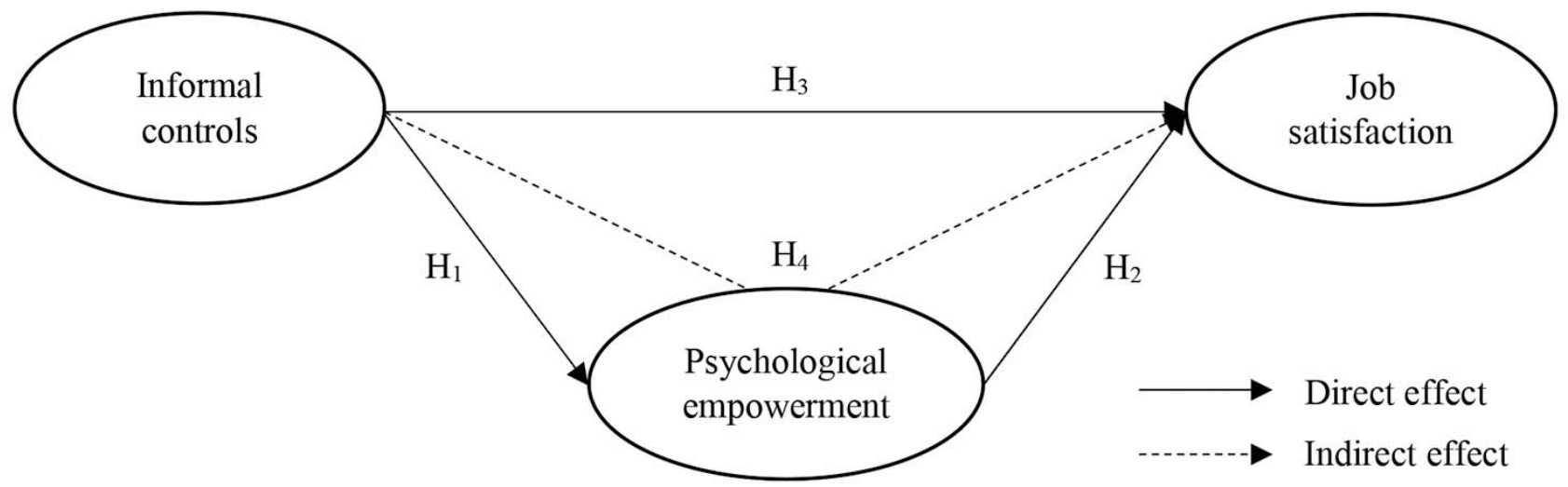

Figure 1 Conceptual model

Note: Control variables: formal controls, age, and gender.

Source: Elaborated by the authors.

\section{METHOD}

\subsection{Context of the Population, Data Collection, and Sample}

Credit unions operate in a similar context to that of banks, but they have their own particularities, such as the intention to maximize the benefits for their members (Maia et al., 2019; Smith et al., 1981). These unions act in enabling access to credit for a wide variety of social classes, which promotes economic growth and local development at various levels, including in the Brazilian context (Favalli et al., 2020). The operational principles of the World Council of Credit Unions (WOCCU) highlight the role of these organizations in promoting human and social development, contemplating aspects such as the commitment of credit unions to hiring and retaining a qualified workforce, as well as promoting the well-being of members/leaders/employees (Marcoux et al., 2021; Mathuva et al., 2017).

The population of the study includes directors and managers of one of the biggest cooperative financial systems in Brazil. This is a century-old institution with more than two thousand agencies that is present in every region of Brazil and has more than five million members. In July of 2021, it had more than BRL 170 billion in assets, as well as BRL 20 billion in net equity. To define the universe investigated, a search was conducted in the LinkedIn platform, which located 1,219 directors or managers registered with and linked to the webpage of the cooperative system in question. After they were contacted and agreed to participate in the investigation, a cover letter and link to access the research instrument were sent. The data collection occurred between November of 2020 and January of 2021 and resulted in 115 respondents, who represent the final sample. The response rate (sample/ population) was $9.43 \%$ and is consistent with similar previous studies (Feder \& Weißenberger, 2021; Frare \& Beuren, 2020).

When elaborating the survey, care was taken to minimize possible problems derived from common method bias (CMB), resulting from data collection using a single method (survey), self-administered by the respondent, who completed all of the items related to their case in the study, whether independent or dependent (Podsakoff \& Organ, 1986). In this sense, the survey sought to offer measures such as didactic instructions and to highlight its anonymity (Podsakoff et al., 2003). Other care taken, this time regarding the data collected, was in relation to non-response bias, which consists of the study sample possibly differing from the perceptions of the other cases from the population that did not answer the survey. As the characteristics of the non-respondents are unknown, a proxy of considering the late respondents as non-respondents is used (Armstrong \& Overton, 1977). When comparing the means of the answers to the constructs between the first 20 and last 20 respondents, no significant differences were found (lowest $p$-value $=$ 0.189 ), which enables the existence of non-response bias problems to be discarded.

With relation to the profile of the final sample, some observations can be made. The age range of the respondents varies between 23 and 76 years old, with a mean of 36 . Regarding gender, $57.36 \%$ of the respondents are male and 
$42.61 \%$ are female. With relation to schooling, 26 (22.61\%) are graduates or undergraduates and $89(77.38 \%)$ are postgraduates, masters in business administration (MBAs), or masters. Regarding their area of work, 103 of the respondents work in singular units, six work in central units, and six work in the national federation. Finally, the study outlined the selection of directors and managers from the cooperative financial system in question, but there is no control over whether they are from different business units or if two or more respondents happen to be from the same unit. However, this does not appear to be a limitation, as the focus of the study is the informal controls reflected in the cooperative system as a whole and their respective association with variables at the individual level of its directors and managers. Similar perspectives can be found in studies from the management and business area (Frare \& Beuren, 2020; Mucci et al., 2016; Oyadomari et al., 2018).

\subsection{Measuring the Variables}

The latent constructs of the study were collected via multi-items, all of which were adopted from the previous literature and were faithful to the original instrument (see Appendix A for more details on the research instrument and respective psychometric properties). The items were captured on a 7-point Likert-type scale, where 1 represents total disagreement and 7 indicates total agreement. The exogenous variable (informal controls) is a second-order construct composed of two first-order constructs: personnel controls (five items) and cultural controls (five items), both adopted from Kleine and Weißenberger (2014). The operationalization of the mediating variable (psychological empowerment) is aligned with the original conception of a multifaceted construct that contemplates four dimensions (Thomas \& Velthouse, 1990). In light of that, it is operationalized as a second-order construct that contemplates four first-order constructs - meaning, competence, selfdetermination, and impact - each one with three items adopted from Spreitzer (1995). The endogenous variable (job satisfaction) is composed of four items adopted from Macintosh and Krush (2014), which are in turn based on Rutherford et al. (2009).

Three control variables were considered. The first consists of the formal controls (second-order), composed of two first-order constructs: result controls (five items) and action controls (five items), adopted from Kleine and Weißenberger (2014). The inclusion of that control variable answers the call to consider formal control mechanisms together with informal ones [for more details, see Goebel \& Weißenberger (2017b)]. The second is the respondent's age, operationalized in a binary way $(0=$ up to 35 years old; 1 = over 35 years old), using division derived from the median. Similar studies suggest controlling the individuals' age variable in a dichotomous way (Frare $\&$ Beuren, 2020; Monteiro \& Lunkes, 2021). The third, also binary, is gender ( $0=$ male; $1=$ female). Related studies suggest that, depending on the environment and context, age and gender can be determinants of job satisfaction (Bellmann \& Hübler, 2020; Chan, 2019).

In understanding that all the data derive from the same method and a self-administered questionnaire, the possibility of CMB problems should be observed (Podsakoff \& Organ, 1986). From conducting Harman's single factor test, nine factors were found with an eigenvalue higher than 1 , accounting for $79.13 \%$ of the total variance. The first factor represents $40.46 \%$ of the variance, which shows that a single factor cannot explain more than $50 \%$ of the total variance of the model, so CMB is not a problem (Podsakoff et al., 2003).

\subsection{Techniques Applied in the Data Analysis}

Two techniques were employed for the data analysis. Initially, PLS-SEM was used, given its applicability in the context of management research, its robustness in relation to the absence of data normality, as well as it allowing for modeling with certain degrees of complexity (Hair et al., 2019). For that reason, it was necessary to consider the sample power. The $\mathrm{G}^{\star}$ Power 3.1 software was used, in which, using a mean effect size $\left(\mathrm{f}^{2}\right)$ of 0.15 , a err prob of 0.05 , power ( $1-\beta$ err prob) of 0.80 , and five predictors in the variable with the highest number of received arrows, a minimum of 92 cases are required (Faul et al., 2009). Thus, the sample of 115 respondents is satisfactory for the application of PLS-SEM in the conceptual model used.

The second analysis technique used in a complementary way consists of fsQCA. Besides allowing for holistic and asymmetrical analyses (Ragin, 2008), it enables an understanding of the necessary and sufficient causal configurations for achieving a particular result (Fiss, 2007). Using this, an analysis was conducted of necessary and sufficient conditions for the occurrence of a particular result (Ragin, 2008), in this case as conditions (informal controls, psychological empowerment, formal controls, age, and gender) that can lead to the success of the outcome (high job satisfaction). Studies within the context of management control support the use of fsQCA (Bedford et al., 2016; Felício et al., 2021), especially the complementary use of PLS-SEM and fsQCA, respectively (Crespo et al., 2019; Frare \& Beuren, 2020, 2021). In fact, 
by considering a quantitative approach (PLS-SEM) along with a qualitative one (fsQCA), complementary results can be obtained that provide a richer overview (Crespo et al., 2021; Rasoolimanesh et al., 2021).

\section{DATA ANALYSIS}

\subsection{Quantitative Approach: PLS-SEM}

Initially, the measurement model was analyzed (Table 1). The second-order constructs (informal controls and psychological empowerment) were modeled considering a type I (reflexive-reflexive) higher-order structure, using a repeated indicators approach (Sarstedt et al., 2019). Information about the quality of the specific measurement of each first-order construct is available in Appendix A.

Table 1

Measurement model

\begin{tabular}{lcccccccccc}
\hline Variables & $\mathbf{a}$ & $\mathbf{C R}$ & AVE & $\mathbf{1}$ & $\mathbf{2}$ & $\mathbf{3}$ & $\mathbf{4}$ & $\mathbf{5}$ & $\mathbf{6}$ \\
\hline 1. Informal controls & 0.957 & 0.944 & 0.893 & $\mathbf{0 . 9 4 5}$ & 0.501 & 0.703 & 0.814 & 0.262 & 0.055 \\
\hline 2. Psychological empowerment & 0.866 & 0.818 & 0.532 & 0.477 & $\mathbf{0 . 7 2 9}$ & 0.584 & 0.379 & 0.175 & 0.162 \\
\hline 3. Job satisfaction & 0.951 & 0.965 & 0.872 & 0.673 & 0.559 & $\mathbf{0 . 9 3 4}$ & 0.536 & 0.227 & 0.052 \\
\hline 4. Formal controls & 0.934 & 0.946 & 0.897 & 0.772 & 0.358 & 0.510 & $\mathbf{0 . 9 4 7}$ & 0.225 & 0.079 \\
\hline 5. Age & - & - & - & 0.256 & 0.148 & 0.222 & 0.218 & - & 0.056 \\
\hline 6. Gender & - & - & - & 0.043 & 0.013 & 0.051 & 0.053 & -0.056 & - \\
\hline
\end{tabular}

Note: The values in bold on the diagonal represent the square root of the average variance extracted (AVE), the lower left diagonal represents correlations, and the upper right diagonal represents the heterotrait-monotrait ratio of correlations (HTMT) values.

$\alpha=$ Cronbach's alpha; $C R=$ composite reliability.

Source: Elaborated by the authors.

Using confirmatory factor analysis, the factorial loads of all the items (Appendix A) show adequacy (>0.7) (Hair et al., 2017). The internal consistency shows reliability, as the Cronbach's alpha ( $\alpha$ ) and composite reliability (CR) present satisfactory values ( $>0.7)$ (Hair et al., 2019). The convergent validity is adequate ( $>0.5)$ (Hair et al., 2019). Finally, discriminant validity is ensured by the FornellLarcker criteria, with the values on the diagonal in bold (square root of the average variance extracted - AVE) being higher than the correlations between constructs (Hair et al., 2017), and by the heterotrait-monotrait ratio of correlations (HTMT), which presents adequate values $(<0.85)$ (Hair et al., 2019). Having attested the validity of the measurement model, the structural model was then run (Table 2), using bootstrapping with 5,000 resamples, a 95\% confidence interval (CI 95\%) calculation based on the bias-corrected and accelerated (BCA) method, and a two-tailed test.

Table 2

Structural model

\begin{tabular}{lcccccc}
\hline Relationship & Hypothesis & Expected sign & Beta $(\boldsymbol{\beta})$ & t value & p-value & Cl 95\% [2.5; 97.5] \\
\hline $\mathrm{IC} \rightarrow \mathrm{PE}$ & $\mathrm{H}_{1}$ & + & 0.477 & 5.729 & $0.000^{* * *}$ & {$[0.287 ; 0.620]$} \\
\hline $\mathrm{PE} \rightarrow \mathrm{JS}$ & $\mathrm{H}_{2}$ & + & 0.307 & 2.688 & $0.007 * *$ & {$[0.075 ; 0.521]$} \\
\hline $\mathrm{IC} \rightarrow \mathrm{JS}$ & $\mathrm{H}_{3}$ & + & 0.530 & 3.735 & $0.000^{* * *}$ & {$[0.244 ; 0.802]$} \\
\hline $\mathrm{IC} \rightarrow \mathrm{PE} \rightarrow \mathrm{JS}$ & $\mathrm{H}_{4}$ & + & 0.146 & 2.379 & $0.017^{*}$ & {$[0.037 ; 0.276]$} \\
\hline $\mathrm{FC} \rightarrow \mathrm{JS}$ & - & $+/-$ & -0.021 & 0.160 & 0.873 & {$[-0.293 ; 0.237]$} \\
\hline Age $\rightarrow J S$ & - & $+/-$ & 0.047 & 0.836 & 0.403 & {$[-0.064 ; 0.161]$} \\
\hline Gender $\rightarrow J S$ & - & $+/-$ & 0.028 & 0.419 & 0.675 & {$[-0.103 ; 0.159]$} \\
\hline
\end{tabular}

$F C=$ formal controls $; C=$ informal controls; $P E=$ psychological empowerment; $C I$ 95\% $=95 \%$ confidence interval; $J S=$ job satisfaction.

${ }^{*} p<0.05$; ${ }^{* *} p<0.01$; *** $p<0.001$.

Source: Elaborated by the authors. 
Within the scope of the explained variance $\left(\mathrm{R}^{2}\right)$ of psychological empowerment (22\%) and of job satisfaction $(50.8 \%)$, average $(13 \%)$ to high $(26 \%)$ explanatory power is considered for the first, and for the second variable high explanatory power of the exogenous variables is considered (> 26\%) (Cohen, 1988). With relation to predictive accuracy $\left(\mathrm{Q}^{2}\right)$, psychological empowerment $(8.5 \%)$ and job satisfaction (42.8\%) present acceptable values ( $>0$ ) (Hair et al., 2019). Finally, the model does not present multicollinearity, as the variance inflation factor (VIF) values found (1.000-2.833) are adequate (< 3.000) (Hair et al., 2019). Regarding the three control variables included in the model (informal controls, gender, and age), none are perceived to be statistically significant.

\subsection{Qualitative Approach: fsQCA}

The first step in elaborating the fsQCA is to calibrate the data (Ragin, 2008). For the constructs measured based on multi-items, the average score of the items was computed (Crespo et al., 2021) and the theoretical anchors 7 (full-membership), 4 (crossover-point), and 1 (full non-membership) were used (Chang \& Chen, 2014; Galeazzo \& Furlan, 2018; Leischnig et al., 2016) for fuzzification of the data (Ragin, 2008). In addition, the demographic variables (age and gender) were calibrated according to their dichotomous nature (crisp-sets) in relation to the previously-created subgroups (Ragin, 2008).

The second step requires the analysis of necessary conditions for the occurrence of a particular result
(Ragin, 2008). In this sense, the result consists of high job satisfaction. A certain condition (antecedent) may be necessary (consistency higher than 0.90 ) or almost always necessary (consistency higher than 0.80) (Ragin, 2000). After this analysis, it was perceived that psychological empowerment (0.963) is necessary and that informal control (0.890) and formal control (0.836) are almost always necessary. However, despite almost always or always being necessary, it is important to understand if they are sufficient in isolation or in combination to achieve the desired result (Ragin, 2008).

At a third point, a truth table is elaborated, with $2^{\wedge} \mathrm{k}$ rows, in which $k$ is equal to the number of antecedent conditions (Ragin, 2008). To refine this truth table, a consistency threshold equivalent to 0.90 (Chang \& Chen, 2014) is considered to access the sufficient conditions for the occurrence of the desired result (Ragin, 2008), that is, high job satisfaction. This study employs a model for analyzing the sufficient conditions (Table 3 ), considering the constructs of the model together with the control variables. Consistently with Fiss (2011), black circles $(\bullet)$ represent present conditions, white circles with an " $x$ " $(\otimes)$ indicate absent conditions, and the absence of circles indicates indifference. It is important to point out that three types of sufficient solutions are generated (intermediate, parsimonious, and complex) (Ragin, 2008). The study considers the parsimonious and intermediate solutions together, where when the condition appears in both (represented by bigger circles), it figures as a core element, while if it only appears in the intermediate conditions (smaller circles), it represents a peripheral element (Fiss, 2011).

Table 3

Configurations that lead to high job satisfaction

\begin{tabular}{|c|c|c|c|c|}
\hline Conditions & S1 & S2 & S3 & S4 \\
\hline Informal controls & $\bullet$ & $\bullet$ & & \\
\hline Psychological empowerment & $\bullet$ & $\bullet$ & $\bullet$ & $\bullet$ \\
\hline Formal controls & $\bullet$ & & $\bullet$ & $\otimes$ \\
\hline Age $(\otimes=$ up to 35 years old $/ \bullet=$ over 35 years old $)$ & & $\otimes$ & $\otimes$ & \\
\hline Gender $(\otimes=$ male $/ \bullet=$ female $)$ & & & & 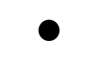 \\
\hline Raw coverage & 0.804 & 0.465 & 0.440 & 0.163 \\
\hline Unique coverage & 0.346 & 0.031 & 0.014 & 0.014 \\
\hline Consistency & 0.976 & 0.973 & 0.951 & 0.957 \\
\hline Overall coverage of the solution & 0.876 & & & \\
\hline Overall consistency of the solution & 0.952 & & & \\
\hline
\end{tabular}

- = presence of the condition; $\otimes=$ absence of the condition.

Cells without circles = indifferent condition; bigger circles = core (essential) conditions; smaller circles = peripheral (complementary) conditions.

Source: Elaborated by the authors. 
In general, the consistency threshold (0.80) of the solutions of each model is satisfactory reached (Ragin, 2008). With relation to coverage, there is the proportion of cases contemplated by the model (overall coverage of the solution), by the solution, including shared with other possible conditions (raw coverage), and by the exclusive solution (unique coverage) (Ragin, 2008).

Four solutions (S) were obtained based on the sufficient conditions analysis. S1 covers the greatest proportion of cases ( $80.4 \%$ of the individuals, $34.6 \%$ of which exclusively) and, independently of age and gender, these achieve high job satisfaction with perceptions of formal and informal controls (essentially) and psychological empowerment (complementarily). S2 and S3 indicate that the youngest individuals (up to 35 years old), independently of gender, achieve high job satisfaction, with the essential presence of informal controls (S2) or of formal controls (S3), as well as psychological empowerment in a complementary way. Finally, S4 reveals that a portion of the women, independently of age, achieve high job satisfaction based on the absence of formal controls and the presence of psychological empowerment.

\subsection{Discussion of the Findings}

$\mathrm{H}_{1}$ suggests that informal controls are positively associated with psychological empowerment. The hypothesis was supported $(\beta=0.477 ; p<0.001)$. The result corroborates studies on MCS that support the beneficial role of interactive (Matsuo et al., 2021) and enabling controls (Baird et al., 2018; Beuren, Santos \& Bernd, 2020) in psychological empowerment. This result, especially within the scope of informal controls, broadens the understanding of their positive effects on organizational commitment (Goebel \& Weißenberger, 2017a), participation (Wohlgemuth et al., 2019), and organizational identification by employees (Monteiro \& Lunkes, 2021), by highlighting positive effects on psychological empowerment.

Informal controls are related with the not-so-explicit managerial procedures collectively accepted by employees (Akroyd \& Kober, 2020; Tucker, 2019). The findings indicate that, for the sample in question, the personnel controls employed to stimulate individuals' motivation, via the organization's core values (Abernethy \& Brownell, 1997), together with cultural controls that seek to establish norms and values expected in the organization (Akroyd \& Kober, 2020; Goebel \& Weißenberger, 2017b), are beneficial for stimulating the meaning of the work, a belief in competency in relation to the activities, selfdetermination, and a feeling of an impact on the work, from the employees' viewpoint (Spreitzer, 1995; Spreitzer et al., 1997).

In $\mathrm{H}_{2}$, it is assumed that psychological empowerment is positively associated with job satisfaction. This hypothesis was supported $(\beta=0.307 ; p<0.01)$. Moreover, psychological empowerment is needed for high job satisfaction and complementarily present in all configurations for high job satisfaction. This result highlights that psychological empowerment has great potential to promote a higher level of job satisfaction in the individual (He et al., 2010) and it reinforces the view that job satisfaction is positively connected with individual results, such as emotional rewards, stability, and job performance and commitment (Koo et al., 2019; Mahmood et al., 2019).

The employees' own motivation or psychological attitude in relation to their work environment (Spreitzer, 1995 ) is perceived to be a fundamental element for them to present a feeling of accomplishment and that their job is worthwhile (Macintosh \& Krush, 2014). As satisfaction is considered as a decisive factor for organizational efficiency and effectiveness (Sandalika \& Jayasekara, 2017), the fact that psychological empowerment is an antecedent element should be revealed. Thus, the employees' meaning, competency, self-determination, and impact in their work environment (Spreitzer, 1995) provide those individuals with a higher degree of satisfaction, which is beneficial for the organization and for the employees (Saridakis et al., 2018).

$\mathrm{H}_{3}$ stipulates that informal controls are positively associated with job satisfaction, and it is supported $(\beta=0.530 ; p<0.001)$. The finding suggests that communications of an informal and flexible nature contribute to organizations having teams of employees who are more satisfied with their work. The confirmation of $\mathrm{H}_{3}$ reinforces the importance of companies planning their actions focusing on the dissemination of core values and resulting socialization, as these less explicit practices have been shown to contribute to job satisfaction (Akroyd \& Kober, 2020; Altenburger, 2021).

In an asymmetric analysis, the role of informal controls in promoting high job satisfaction is observed. Together with formal controls and psychological empowerment, informal controls are widely sought by the managers in the sample studied to achieve high levels of job satisfaction. This perspective is in line with the evidence found by Boff et al. (2021) that both controls - informal and formal - are determinants for organizational trust and commitment. In light of this, the study extends this complementarity perspective to the context of job satisfaction.

$\mathrm{H}_{4}$ suggests that psychological empowerment mediates the relationship between informal controls 
and job satisfaction. The hypothesis was supported $(\beta=0.146 ; p<0.05)$ and, as both effects (direct and indirect) are significant and have the same sign, there is partial and complementary mediation (Hair et al., 2019). This finding initially corroborates previous studies that identify psychological empowerment as a mediator between management controls and organizational or individual results (Beuren, Santos \& Bernd, 2020; Hall, 2008; Matsuo et al., 2021; Souza \& Beuren, 2018), as well as exploring the indirect effects of management controls on exclusively individual results, via mediators of a psychological nature (Hall, 2016; Luft \& Shields, 2003). Moreover, the finding aligns with Monteiro and
Lunkes (2021), who highlighted the role of informal controls in triggering aspects such as organizational identification and affective commitment.

The findings suggest that employees' meaning, competence, self-determination, and impact (Spreitzer, 1995) help them in absorbing and understanding the controls regarding hiring, training, development, and opportunities and codes of conduct, the mission, the vision, and fundamental values (Goebel \& Weißenberger, 2017b; Kleine \& Weißenberger, 2014) of the cooperativist system and in the translation of these controls toward a feeling of accomplishment, emotion, and positive feelings at work (Macintosh \& Krush, 2014).

\section{CONCLUDING REMARKS}

The study analyzed the mediating role of psychological empowerment in the relationship between the informal (personnel and cultural) control and the job satisfaction of representatives of business units of one of the biggest credit union systems in Brazil. Three control variables were explored: formal control mechanisms, age, and gender of the respondents. The findings indicate that informal controls directly and indirectly influence (via psychological empowerment) the job satisfaction of the employees in the sample investigated.

Asymmetrically, informal controls are almost always needed and psychological empowerment is always needed for high job satisfaction. The study reveals the equifinality of sufficient configurations that individuals undergo to achieve high job satisfaction. First, independently of age and gender, the essential presence of informal and formal controls, and complementary presence of psychological empowerment, represents the main solution that individuals use for high job satisfaction. Second, for younger individuals, high job satisfaction is achieved through the complementary presence of psychological empowerment and the essential presence of either informal or formal controls. Third, for a portion of women, the presence of psychological empowerment and absence of formal controls are already sufficient for high job satisfaction. Finally, psychological empowerment is always present in a complementary way, with regard to high job satisfaction.

The study initially has implications for the literature on informal controls, psychological empowerment, and job satisfaction, by answering the call of Hall (2016) and Luft and Shields (2003) for the inclusion of psychological variables between management controls and individual results/behaviors. For as much as psychological empowerment is explored as a mediator in related studies that contemplate the discussion of comprehensive PMSs (Hall, 2008), enabling PMSs (Souza \& Beuren, 2018), an enabling perception of MCS (Beuren, Santos \& Bernd, 2020), and the interactive use of MCS (Matsuo et al., 2021), the present study stands out by exploring the role of informal controls (personnel control and cultural control) (Goebel \& Weißenberger, 2017b; Kleine \& Weißenberger, 2014).

Also with regard to the implications for the literature, the study explores a specific context, of organizations governed by social and collective values (Jovanović et al., 2017). Thus, it answers the call from studies to explore the role of informal controls in particular (Pant, 2001; Tucker, 2019), providing evidence for yet another context of organizations (Goebel \& Weißenberger, 2017b; Monteiro \& Lunkes, 2021; Wohlgemuth et al., 2019). Finally, the methodological contribution stands out by using the emerging mixed methods approach in research within the context of management controls (Crespo et al., 2019; Frare \& Beuren, 2020, 2021), especially by supporting the inclusion of asymmetrical analyses using fsQCA (Bedford et al., 2016; Felício et al., 2021; Rasoolimanesh et al., 2021).

The findings enable the implications for management practice to be debated, especially in cooperative systems. The perception of controls focused on hiring, training, and opportunities (personnel control) and codes of conduct, the mission, and core values (cultural control) (Goebel \& Weißenberger, 2017b; Kleine \& Weißenberger, 2014) is shown to be reflected in individual behaviors, whether in the significance of the work (meaning), beliefs in accomplishment (competence), autonomy (self-determination), and impactful results (impact) (psychological empowerment) (Spreitzer, 1995), as well as job satisfaction, which can be vital for ensuring the permanence (employability) and positive behaviors of 
employees. Understanding the antecedents of job satisfaction is also important for organizations, as this triggers various developments, such as employees' loyalty (Dhir et al., 2020) and job performance (Eliyana \& Maarif, 2019). In this sense, the findings present insights on the way in which informal controls are conducted by the cooperativist system and how they can be beneficial for individuals in the workplace, especially managers of business units.

Finally, some limitations should be pointed out. Caution should be taken when generalizing the results, due to the cross-sectional study design and the fact that the study covers a single credit union system in the Brazilian context.
So, future research could consider longitudinal studies, other cooperative systems (e.g. agricultural and health), and even samples from other countries, with different cultures and economies. The study employs a mediating variable (psychological empowerment) in the relationship between informal controls and job satisfaction, which points to opportunities for the inclusion of other possible psychological variables as intervening ones. Finally, the study essentially considers informal controls and formal controls are analyzed as a control variable. Therefore, new research could consider other typologies and perspectives within the scope of MCS.

\section{REFERENCES}

Abernethy, M. A., \& Brownell, P. (1997). Management control systems in research and development organizations: The role of accounting, behavior and personnel controls. Accounting, Organizations and Society, 22(3-4), 233-248. https://doi. org/10.1016/S0361-3682(96)00038-4

Akroyd, C., \& Kober, R. (2020). Imprinting founders' blueprints on management control systems. Management Accounting Research, 46, 1-18, 100645. https://doi.org/10.1016/j. mar.2019.07.002

Altenburger, M. (2021). Mood and honesty in budget reporting. Management Accounting Research, 50, 1-12, 100707. https:// doi.org/10.1016/j.mar.2020.100707

Armstrong, J. S., \& Overton, T. S. (1977). Estimating nonresponse bias in mail surveys. Journal of Marketing Research, 14(3), 396-402. https://doi.org/10.1177/002224377701400320

Baird, K., Su, S., \& Munir, R. (2018). The relationship between the enabling use of controls, employee empowerment, and performance. Personnel Review, 47(1), 257-274. https://doi. org/10.1108/PR-12-2016-0324

Barton, H., \& Barton, L. C. (2011). Trust and psychological empowerment in the Russian work context. Human Resource Management Review, 21(1), 201-208. https://doi. org/10.1016/j.hrmr.2011.02.001

Bedford, D. S., Malmi, T., \& Sandelin, M. (2016). Management control effectiveness and strategy: An empirical analysis of packages and systems. Accounting, Organizations and Society, 51, 12-28. https://doi.org/10.1016/j.aos.2016.04.002

Bellmann, L., \& Hübler, O. (2020). Working from home, job satisfaction and work-life balance-robust or heterogeneous links? International Journal of Manpower, 42(3), 424-441. https://doi.org/10.1108/IJM-10-2019-0458

Beuren, I. M., Santos, V. D., \& Bernd, D. C. (2020). Effects of the management control system on empowerment and organizational resilience. BBR. Brazilian Business Review, 17(2), 211-232. https://doi.org/10.15728/bbr.2020.17.2.5

Beuren, I. M., Santos, V. D., Bernd, D. C., \& Pazetto, C. F. (2020). Reflexos do compartilhamento de informações e da inovação colaborativa na responsabilidade social de cooperativas.
Revista Brasileira de Gestão de Negócios, 22, 310-330. https:// doi.org/10.7819/rbgn.v22i2.4052

Boff, M. L., Savariz, C. R., \& Beuren, I. M. (2021). Influência dos controles formais e informais e da confiança no comprometimento organizacional. Revista de Educação e Pesquisa em Contabilidade (REPeC), 15(1), 110-127. https:// doi.org/10.17524/repec.v15i1.2698

Bordin, C., Bartram, T., \& Casimir, G. (2006). The antecedents and consequences of psychological empowerment among Singaporean IT employees. Management Research News, 30(1), 34-46. https://doi.org/10.1108/01409170710724287

Carbonell, P., \& Rodriguez-Escudero, A. I. (2013). Management control, role expectations and job satisfaction of new product development teams: The moderating effect of participative decision-making. Industrial Marketing Management, 42(2), 248-259. https://doi.org/10.1016/j.indmarman.2012.08.007

Cardinal, L. B., Sitkin, S. B., \& Long, C. P. (2004). Balancing and rebalancing in the creation and evolution of organizational control. Organization Science, 15(4), 411-431. https://doi. org/10.1287/orsc. 1040.0084

Carless, S. A. (2004). Does psychological empowerment mediate the relationship between psychological climate and job satisfaction? Journal of Business and Psychology, 18(4), 405425. https://doi.org/10.1023/B:JOBU.0000028444.77080.c5

Chan, S. C. (2019). Participative leadership and job satisfaction: The mediating role of work engagement and the moderating role of fun experienced at work. Leadership \& Organization Development Journal, 40(3), 319-333. https://doi.org/10.1108/ LODJ-06-2018-0215

Chang, M. L., \& Cheng, C. F. (2014). How balance theory explains high-tech professionals' solutions of enhancing job satisfaction. Journal of Business Research, 67(9), 2008-2018. https://doi.org/10.1016/j.jbusres.2013.10.010

Chenhall, R. H. (2003). Management control systems design within its organizational context: Findings from contingencybased research and directions for the future. Accounting, Organizations and Society, 28(2-3), 127-168. https://doi. org/10.1016/S0361-3682(01)00027-7 
Chenhall, R. H., \& Brownell, P. (1988). The effect of participative budgeting on job satisfaction and performance: Role ambiguity as an intervening variable. Accounting, Organizations and Society, 13(2), 225-233, https://doi. org/10.1016/0361-3682(88)90001-3

Cohen, J. (1988). Statistical power analysis for the behavioral sciences (2a. ed.). Psychology Press.

Crespo, N. F., Curado, C., Oliveira, M., \& Muñoz-Pascual, L. (2021). Entrepreneurial capital leveraging innovation in micro firms: A mixed-methods perspective. Journal of Business Research, 123, 333-342. https://doi.org/10.1016/j. jbusres.2020.10.001

Crespo, N. F., Rodrigues, R., Samagaio, A., \& Silva, G. M. (2019). The adoption of management control systems by start-ups: Internal factors and context as determinants. Journal of Business Research, 101, 875-884. https://doi.org/10.1016/j. jbusres.2018.11.020

Dhir, S., Dutta, T., \& Ghosh, P. (2020). Linking employee loyalty with job satisfaction using PLS-SEM modelling. Personnel Review, 49(8), 1695-1711. https://doi.org/10.1108/PR-032019-0107

Dimes, R., \& Villiers, C. (2020). How management control systems enable and constrain integrated thinking. Meditari Accountancy Research, 29(4), 851-872. https://doi. org/10.1108/MEDAR-05-2020-0880

Eliyana, A., \& Ma'arif, S. (2019). Job satisfaction and organizational commitment effect in the transformational leadership towards employee performance. European Research on Management and Business Economics, 25(3), 144-150. https://doi.org/10.1016/j.iedeen.2019.05.001

Faul, F., Erdfelder, E., Buchner, A., \& Lang, A. G. (2009). Statistical power analyses using $G^{\star}$ Power 3.1: Tests for correlation and regression analyses. Behavior Research Methods, 41(4), 11491160. https://doi.org/10.3758/BRM.41.4.1149

Favalli, R. T., Maia, A. G., \& Silveira, J. M. F. J. da. (2020). Governance and financial efficiency of Brazilian credit unions. RAUSP Management Journal, 55(3), 355-373. https://doi. org/10.1108/rausp-02-2019-0018

Feder, M., \& Weißenberger, B. E. (2021). Towards a holistic view of CSR-related management control systems in German companies: Determinants and corporate performance effects. Journal of Cleaner Production, 294, 1-14, 126084. https://doi. org/10.1016/j.jclepro.2021.126084

Felício, T., Samagaio, A., \& Rodrigues, R. (2021). Adoption of management control systems and performance in public sector organizations. Journal of Business Research, 124, 593602. https://doi.org/10.1016/j.jbusres.2020.10.069

Ferris, K. R. (1977). Perceived uncertainty and job satisfaction in the accounting environment. Accounting, Organizations and Society, 2(1), 23-28, https://doi.org/10.1016/03613682(77)90004-6

Fiss, P. C. (2007). A set-theoretic approach to organizational configurations. Academy of Management Review, 32(4), 11801198. https://doi.org/10.5465/amr.2007.26586092
Fiss, P. C. (2011). Building better causal theories: A fuzzy set approach to typologies in organization research. Academy of Management Journal, 54(2), 393-420. https://doi.org/10.5465/ amj.2011.60263120

Frare, A. B., \& Beuren, I. M. (2020). Effects of information on job insecurity and work engagement in times of pandemic. Revista de Administração de Empresas, 60(6), 400-412. https:// doi.org/10.1590/S0034-759020200604

Frare, A. B., \& Beuren, I. M. (2021). Fostering individual creativity in startups: Comprehensive performance measurement systems, role clarity and strategic flexibility. European Business Review, in press. http://doi.org/10.1108/EBR-11-2020-0262

Galeazzo, A., \& Furlan, A. (2018). Lean bundles and configurations: A fsQCA approach. International Journal of Operations and Production Management, 38(2), 513-533. https://doi.org/10.1108/IJOPM-11-2016-0657

Goebel, S, \& Weißenberger, B. E. (2017a). Effects of management control mechanisms: Towards a more comprehensive analysis. Journal of Business Economics, 87(2), 185-219. https://doi. org/10.1007/s11573-016-0816-6

Goebel, S, \& Weißenberger, B. E. (2017b). The relationship between informal controls, ethical work climates, and organizational performance. Journal of Business Ethics, 141, 505-528. https://doi.org/ 10.1007/s10551-015-2700-7

Hair, J. F., Jr., Hult, G. T. M., Ringle, C. M., \& Sarstedt, M. (2017). A primer on partial least squares structural equation modeling (PLS-SEM). Sage.

Hair, J. F., Jr., Risher, J. J., Sarstedt, M., \& Ringle, C. M. (2019). When to use and how to report the results of PLS-SEM. European Business Review, 31(1), 2-24. https://doi. org/10.1108/EBR-11-2018-0203

Hall, M. (2008). The effect of comprehensive performance measurement systems on role clarity, psychological empowerment and managerial performance. Accounting, Organizations and Society, 33(2-3), 141-163. https://doi. org/10.1016/j.aos.2007.02.004

Hall, M. (2016). Realising the richness of psychology theory in contingency-based management accounting research. Management Accounting Research, 31, 63-74. https://doi. org/10.1016/j.mar.2015.11.002

He, P., Murrmann, S. K., \& Perdue, R. R. (2010). An investigation of the relationships among employee empowerment, employee perceived service quality, and employee job satisfaction in a U.S. hospitality organization. Journal of Foodservice Business Research, 13(1), 36-50. https://doi. org/10.1080/15378021003595947

Jovanović, T., Arnold, C., \& Voigt, K. I. (2017). Cooperative banks in need of transition: The influence of Basel III on the business model of German cooperative credit institutions. Journal of Co-operative Organization and Management, 5(1), 39-47. https://doi.org/10.1016/j.jcom.2017.03.003

Kleine, C., \& Weißenberger, B. E. (2014). Leadership impact on organizational commitment: The mediating role of management control systems choice. Journal of Management 
Control, 24(3), 241-266. https://doi.org/10.1007/s00187-0130181-3

Koo, B., Yu, J., Chua, B. L., Lee, S., \& Han, H. (2019). Relationships among emotional and material rewards, job satisfaction, burnout, affective commitment, job performance, and turnover intention in the hotel industry. Journal of Quality Assurance in Hospitality \& Tourism, 20(1), 1-31. https://doi.org/10.1080/1528008X.2019.1663572

Langfield-Smith, K. (1997). Management control systems and strategy: A critical review. Accounting, Organizations and Society, 22(2), 207-232, https://doi.org/10.1016/S03613682(95)00040-2

Leischnig, A., Henneberg, S. C., \& Thornton, S. C. (2016). Net versus combinatory effects of firm and industry antecedents of sales growth. Journal of Business Research, 69(9), 35763583. https://doi.org/10.1016/j.jbusres.2016.01.005

Luft, J., \& Shields, M. D. (2003). Mapping management accounting: Graphics and guidelines for theory-consistent empirical research. Accounting, Organizations and Society, 28(2-3), 169-249. https://doi.org/10.1016/S03613682(02)00026-0

Macintosh, G., \& Krush, M. (2014). Examining the link between salesperson networking behaviors, job satisfaction, and organizational commitment: Does gender matter? Journal of Business Research, 67(12), 2628-2635. https://doi. org/10.1016/j.jbusres.2014.03.022

Mahmood, A., Akhtar, M. N., Talat, U., Shuai, C., \& Hyatt, J. C. (2019). Specific HR practices and employee commitment: The mediating role of job satisfaction. Employee Relations: The International Journal, 41(4), 420-435. https://doi.org/10.1108/ ER-03-2018-0074

Maia, S. C., de Benedicto, G. C., Prado, J. W. do, Robb, D. A., Bispo, O. N. A, \& Brito, M. J. de. (2019). Mapping the literature on credit unions: A bibliometric investigation grounded in Scopus and Web of Science. Scientometrics, 120(3), 929-960. https://doi.org/10.1007/s11192-019-03165-1

Marcoux, G., Guihur, I., \& Leclerc, A. (2021). Co-operative difference and organizational commitment: The filter of sociodemographic variables. The International Journal of Human Resource Management, 32(4), 822-845. https://doi.org/10.1080 /09585192.2018.1504105

Mathuva, D. M., Mboya, J. K., \& McFie, J .B. (2017). Achieving legitimacy through co-operative governance and social and environmental disclosure by credit unions in a developing country. Journal of Applied Accounting Research, 18(2), 162184. https://doi.org/10.1108/JAAR-12-2014-0128

Matsuo, M., Matsuo, T., \& Arai, K. (2021). The influence of an interactive use of management control on individual performance: Mediating roles of psychological empowerment and proactive behavior. Journal of Accounting and Organizational Change, 17(2), 263-281. https://doi. org/10.1108/JAOC-06-2020-0079

Merchant, K. A. (1985). Control in business organizations. Financial Times/Prentice Hall.
Merchant, K. A., \& Van der Stede, W. A. (2007). Management control systems: Performance measurement, evaluation and incentives ( $2^{\text {nd }}$ ed.). Pearson Education.

Merchant, K. A., Van der Stede, W. A., \& Zheng, L. (2003). Disciplinary constraints on the advancement of knowledge: The case of organizational incentive systems. Accounting, Organizations and Society, 28(2-3), 251-286. https://doi. org/10.1016/S0361-3682(01)00051-4

Meyerson, S. L., \& Kline, T. J. (2008). Psychological and environmental empowerment: Antecedents and consequences. Leadership \& Organization Development Journal, 29(5), 444-460. https://doi. org/10.1108/01437730810887049

Monteiro, J. J., \& Lunkes, R. J. (2021). Efeitos dos controles informais e da identificação organizacional no comprometimento afetivo. Journal of Globalization, Competitiveness and Governability, 15(2). https://doi. org/10.3232/GCG.2021.V15.N2.03

Mucci, D. M., Frezatti, F., \& Dieng, M. (2016). As múltiplas funções do orçamento empresarial. Revista de Administração Contemporânea, 20(3), 283-304. https://doi.org/10.1590/19827849rac2016140121

Norris, D. R. \& Niebuhr, R. E. (1984). Professionalism, organizational commitment and job satisfaction in an accounting organization. Accounting, Organizations and Society, 9(1), 49-59, https://doi.org/10.1016/03613682(84)90029-1

Norris, G., \& O'Dwyer, B. (2004). Motivating socially responsive decision making: The operation of management controls in a socially responsive organisation. The British Accounting Review, 36(2), 173-196. https://doi.org/10.1016/j. bar.2003.11.004

Oyadomari, J .C. T., Duque, B., Nisiyama, E. K., Dultra-deLima, R. G., \& Mendonça Neto, O. R. D. (2018). Uso de relatórios gerenciais e desempenho de gerentes comerciais em companhia seguradora. Revista Contabilidade \& Finanças, 29(78), 343-354. https://doi.org/10.1590/1808-057x201805970

Pant, L. W. (2001). The growing role of informal controls: Does organization learning empower or subjugate workers? Critical Perspectives on Accounting, 12(6), 697-712. https://doi. org/10.1006/cpac.2001.0475

Penha, E. D. S., Rebouças, S. M. D. P., Abreu, M. C. S., \& Parente, T. C. (2016). Percepção de responsabilidade social e satisfação no trabalho: um estudo em empresas brasileiras. REGE Revista de Gestão, 23, 306-315. https://doi.org/10.1016/j. rege.2016.09.006

Pfister, J. A., \& Lukka, K. (2019). Interrelation of controls for autonomous motivation: A field study of productivity gains through pressure-induced process innovation. The Accounting Review, 94(3), 345-371. https://doi.org/10.2308/accr-52266

Podsakoff, P. M., \& Organ, D. W. (1986). Self-reports in organizational research: Problems and prospects. Journal of Management, 12(4), 531-544. https://doi. org/10.1177/014920638601200408 
Podsakoff, P., MacKenzie, S., Lee, J. Y., \& Podsakoff, N. (2003). Common method biases in behavioral research: A critical review of the literature and recommended remedies. Journal of Applied Psychology, 88(5), 879-903. https://doi. org/10.1037/0021-9010.88.5.879

Ragin, C. C. (2000). Fuzzy-set social science. University of Chicago Press.

Ragin, C. C. (2008). Redesigning social inquiry: Fuzzy sets and beyond. University of Chicago Press.

Rajabi, R., Boles, J., Alejandro, T. G. B., \& Sarin, S. (2021). Revisiting and replicating the dominant logic on salesperson job satisfaction, organizational commitment, and turnover. Journal of Business Research, 126, 524-532, https://doi. org/10.1016/j.jbusres.2019.10.067

Rasoolimanesh, S. M., Ringle, C. M., Sarstedt, M., \& Olya, H. (2021). The combined use of symmetric and asymmetric approaches: Partial least squares-structural equation modeling and fuzzy-set qualitative comparative analysis. International Journal of Contemporary Hospitality Management, 33(5), 1571-1592. https://doi.org/10.1108/ IJCHM-10-2020-1164

Rutherford, B., Boles, J., Hamwi, G. A., Madupalli, R., \& Rutherford, L. (2009). The role of the seven dimensions of job satisfaction in salesperson's attitudes and behaviors. Journal of Business Research, 62(11), 1146-1151. https://doi. org/10.1016/j.jbusres.2008.10.019

Sandalika, K. D. M., \& Jayasekara, P. (2017). Impact of performance management system on employee job satisfaction in automobile companies in Western Province, Sri Lanka. Human Resource Management Journal, 5(1), 1-18. https://doi.org/10.31357/hrmj.v5i1.3572

Saridakis, G., Lai, Y., Muñoz Torres, R. I., \& Gourlay, S. (2018). Exploring the relationship between job satisfaction and organizational commitment: An instrumental variable approach. The International Journal of Human Resource Management, 29(1), 1-31. https://doi.org/10.1080/09585192.2 017.1423100

Sarstedt, M., Hair, J. F., Jr., Cheah, J. H., Becker, J. M., \& Ringle, C. M. (2019). How to specify, estimate, and validate higherorder constructs in PLS-SEM. Australasian Marketing Journal, 27(3), 197-211. https://doi.org/10.1016/j.ausmj.2019.05.003

Siegall, M., \& Gardner, S. (2000). Contextual factors of psychological empowerment. Personnel Review, 29(6), 703722. https://doi.org/10.1108/00483480010296474
Silva, C. D., Silva, C. T. D., Mucci, D. M., \& Beck, F. (2021). Explorando a interdependência entre gainsharing e avaliação de desempenho em uma cooperativa de crédito. Revista Contabilidade \& Finanças, 32(87), 398-412. https://doi. org/10.1590/1808-057x202112270

Smith, D. J., Cargill, T. F., \& Meyer, R. A. (1981). Credit unions: An economic theory of a credit union. Journal of Finance, 36(2), 519-528. https://doi.org/10.1111/j.1540-6261.1981. tb00470.x

Song, Z., Chon, K., Ding, G., \& Gu, C. (2015). Impact of organizational socialization tactics on newcomer job satisfaction and engagement: Core self-evaluations as moderators. International Journal of Hospitality Management, 46, 180-189. https://doi.org/10.1016/j.ijhm.2015.02.006

Souza, G. E. D., \& Beuren, I. M. (2018). Reflexos do sistema de mensuração de desempenho habilitante na performance de tarefas e satisfação no trabalho. Revista Contabilidade \& Finanças, 29(77), 194-212. https://doi.org/10.1590/1808$057 \times 201805850$

Spreitzer, G. M. (1995). Psychological empowerment in the workplace: Dimensions, measurement, and validation. Academy of Management Journal, 38(5), 1442-1465. https:// doi.org/10.2307/256865

Spreitzer, G. M., Kizilos, M. A., \& Nason, S. W. (1997). A dimensional analysis of the relationship between psychological empowerment and effectiveness satisfaction, and strain. Journal of Management, 23(5), 679-704. https:// doi.org/10.1016/S0149-2063(97)90021-0

Thomas, K. W., \& Velthouse, B. A. (1990). Cognitive elements of empowerment: An "interpretive" model of intrinsic task motivation. Academy of Management Review, 15(4), 666-681. https://doi.org/10.2307/258687

Tucker, B. P. (2019). Heard it through the grapevine: Conceptualizing informal control through the lens of social network theory. Journal of Management Accounting Research, 31(1), 219-245. https://doi.org/10.2308/jmar-52064

Williams, D. J. (1986). Shareholder bonding in financial mutuals: An exploratory study of the relative effects of altruism and agency. Accounting, Organizations and Society, 11(3), 271-286. https://doi.org/10.1016/0361-3682(86)90025-5

Wohlgemuth, V., Wenzel, M., Berger, E. S., \& Eisend, M. (2019). Dynamic capabilities and employee participation: The role of trust and informal control. European Management Journal, 37(6), 760-771. https://doi.org/10.1016/j.emj.2019.02.005 


\section{APPENDIX A}

Research instrument and psychometric properties

\begin{tabular}{|c|c|c|}
\hline \multicolumn{2}{|c|}{ Informal controls (second-order) $(\alpha=0.957 ; \mathrm{CR}=0.944 ; \mathrm{AVE}=0.893)$} & \multirow[t]{2}{*}{ Factorial loads } \\
\hline & Personnel controls (first-order) $(\alpha=0.926 ; C R=0.944 ; A V E=0.773)$ & \\
\hline PC1 & The employees are carefully selected and fit the organization's norms and values. & 0.879 \\
\hline PC2 & $\begin{array}{l}\text { A lot of effort was made in establishing the most appropriate recruitment process for our } \\
\text { organization. }\end{array}$ & 0.915 \\
\hline PC3 & Emphasis is placed on hiring the most suitable candidates for a particular position. & 0.910 \\
\hline PC4 & Training and development activities are considered to be very important. & 0.881 \\
\hline \multirow[t]{2}{*}{ PC5 } & The employees receive numerous opportunities to widen their range of skills. & 0.806 \\
\hline & Cultural controls (first-order) $(\alpha=0.953 ; C R=0.964 ; A V E=0.842)$ & \\
\hline CC1 & $\begin{array}{l}\text { In our organization, great emphasis is placed on sharing informal codes of conduct with the } \\
\text { employees. }\end{array}$ & 0.881 \\
\hline $\mathrm{CC} 2$ & Our mission statement conveys the organization's core values to our employees. & 0.906 \\
\hline $\mathrm{CC} 3$ & The senior managers communicate the organization's core values to the employees. & 0.933 \\
\hline $\mathrm{CC} 4$ & The employees are aware of the organization's fundamental values. & 0.952 \\
\hline CC5 & The employees consider the values set out in our mission statement to be motivating. & 0.913 \\
\hline \multicolumn{3}{|c|}{ Formal controls (second-order) $(\alpha=0.934 ; C R=0.946 ; \mathrm{AVE}=0.897)$} \\
\hline & Result controls (first-order) $(\alpha=0.861 ; C R=0.901 ; A V E=0.647)$ & \\
\hline RC1 & Specific performance goals ate established for the employees. & 0.853 \\
\hline $\mathrm{RC} 2$ & Achievement of the employees' performance goals is controlled by their respective superiors. & 0.854 \\
\hline RC3 & Possible deviations from performance goals have to be explained by the employees. & 0.738 \\
\hline RC4 & $\begin{array}{l}\text { The employees receive feedback from their superiors about how much they have achieved } \\
\text { their performance goals. }\end{array}$ & 0.860 \\
\hline \multirow[t]{2}{*}{ RC5 } & The variable components of remuneration are linked to the performance goals set. & 0.702 \\
\hline & Action controls (first-order) $(\alpha=0.922 ; C R=0.942 ; A V E=0.764)$ & \\
\hline $\mathrm{AC} 1$ & $\begin{array}{l}\text { Superiors monitor the necessary steps in relation to achieving the performance goals of their } \\
\text { employees. }\end{array}$ & 0.884 \\
\hline AC2 & Superiors evaluate the way the employees carry out a set task. & 0.927 \\
\hline AC3 & Superiors define the most important work steps for routine tasks. & 0.890 \\
\hline AC4 & $\begin{array}{l}\text { Superiors provide the employees with information about the most important steps in relation } \\
\text { to achieving the performance goals. }\end{array}$ & 0.879 \\
\hline AC5 & The policies and procedures manuals define the fundamental course of processes. & 0.784 \\
\hline \multicolumn{3}{|c|}{ Psychological empowerment (second-order) $(\alpha=0.866 ; \mathrm{CR}=0.818 ; \mathrm{AVE}=0.532)$} \\
\hline & Meaning (first-order) $(\alpha=0.917 ; C R=0.948 ; A V E=0.859)$ & \\
\hline MEAN1 & The work I do is very important to me. & 0.891 \\
\hline MEAN2 & My job activities are personally meaningful for me. & 0.947 \\
\hline \multirow[t]{2}{*}{ MEAN3 } & The work I do is meaningful for me. & 0.940 \\
\hline & Competence (first-order) $(\alpha=0.867 ; C R=0.919 ; A V E=0.791)$ & \\
\hline $\mathrm{CO} 1$ & I am confident about my ability to do my job. & 0.917 \\
\hline $\mathrm{CO} 2$ & I am self-assured about my capabilities to perform my work activities. & 0.930 \\
\hline \multirow[t]{2}{*}{$\mathrm{CO} 3$} & I have mastered the skills necessary for my job. & 0.816 \\
\hline & Self-determination (first-order) $(\alpha=0.835 ; C R=0.901 ; A V E=0.752)$ & \\
\hline SD1 & I have significant autonomy to determine how I do my job. & 0.822 \\
\hline SD2 & I can decide alone how to do my job. & 0.874 \\
\hline SD3 & I have considerable opportunities for independence and freedom in the way I do my job. & 0.903 \\
\hline
\end{tabular}


Cont.

Informal controls (second-order) $(\alpha=0.957 ; \mathrm{CR}=0.944 ; \mathrm{AVE}=\mathbf{0 . 8 9 3})$

Factorial loads

\begin{tabular}{lll}
\hline & Impact (first-order) $(\boldsymbol{\alpha}=\mathbf{0 . 7 3 1} ; \boldsymbol{C R}=\mathbf{0 . 8 4 9} ; \boldsymbol{A V E}=\mathbf{0 . 6 5 5})$ & 0.705 \\
\hline IMP1 & My impact over what happens in my department is large. & 0.830 \\
\hline IMP2 & I have a great deal of control over what happens in my department. & 0.883 \\
\hline IMP3 & I have significant influence over what happens in my department. & 0.936 \\
\hline Job satisfaction $(\boldsymbol{\alpha}=\mathbf{0 . 9 5 1} ; \mathbf{C R}=\mathbf{0 . 9 6 5 ;}$ AVE $=\mathbf{0 . 8 7 2})$ & 0.921 \\
\hline JS1 & It gives me a sense of accomplishment. & 0.942 \\
\hline JS2 & It is exciting. & 0.937 \\
\hline JS3 & It is satisfying. & \\
\hline
\end{tabular}

$\alpha=$ Cronbach's alpha; $A V E=$ average variance extracted; $C R=$ composite reliability.

Source: Elaborated by the authors. 